graphs. I also thank Dr. R. A. Beatty for discussion, and Prof. C. H. Waddington for his interest.

Institute of Animal Genetics,

\section{G. G. Shlman}

University of Edinburgh.

${ }^{1}$ Conklin, E. G., J. Exp. Zool., 22, 311 (1917). 2 Wilson, E. B., The Cell in Development and Heredity (Macmillan, Now
York, 1928).

${ }^{3}$ Mazia, D., in The Cell, 3 (Academic Press, New York and London, 1961).

${ }^{4}$ Harvey, E. B., Biol. Bull., 66, 228 (1934).

¿Clement, A. C., Biol. Bull., 69, 403 (1935).

6 Kawamura, K., Exp. Cell. Res, 21, 9 (1960).

'Kawamura, K., and Carlson, J. C., Exp. Cell. Res., 26, 411 (1962).

' Kawamura, K., and Carison, J. C., Exp. Cell. Res., 26,

' Wolpert, L., Int. Rev. Cytology, 10, 163 (1960).

${ }^{10}$ Chambers, R., J. Exp. Zool., 28, 483 (1917).

${ }^{11}$ Raven, C. P., J. Embryol. Exp. Morph., 12, 805 (1964),

${ }^{12}$ Austin, C. R., The Mammalian Egg (Blackwell, Oxford, 1961).

${ }^{13}$ Austin, C. R., J. Roy. Micros. Soc., 75, 141 (1956).

${ }_{14}$ Austin, C. R., and Braden, A. W. H., Austral. J. Biol. Sci., 7, 195 (1954).

15 Odor, D. I., and Renniger, D. F., Anat. Rec., 13\%, 13 (1960).

${ }_{18}$ Austin, C. R., and Walton, A., in Marshall's Physiology of Reproduction, thistin, C. R., and Walton, A., in Marshall's Physiology

${ }^{17}$ Selman, G. G., and Waddington, C. H., J. Exp. Biol., 32, 700 (1955).

${ }^{18}$ Mitchison, J. M., and Swann, M. M., J. Exp. Biol., 29, 357 (1952).

t9 Robbins, E., and Gonatas, N. K., J. Cell Biol., 20, 356 (1964).

${ }^{20}$ Robbins, E., and Gonatas, N. K., J. Cell Biol.,21, 429 (1964).

\section{Oxytocin and the Life-span of Male Rats}

Friedman and Friedman ${ }^{1}$ recently reported that chronic administration of a crude extract of the posterior pituitary gland extended the life-span of old male rats. They postulated that this offoct rosulted from changes caused by vasopressin in the metabolism of water and salts. Vasopressin alone, however, failed to produce prolongation of life in the aforementioned experiments. More recently, they have extended their investigations to the effect of aldosterone.

It seemed to us not unreasonable to assume that the effect on life span of posterior pituitary extracts is attributable, at least in part, to their content of oxytocin rather than of vasopressin. Tho possibility that a third, perhaps yet unknown, factor is present in the gland has not been overlooked.

In the investigation reported here, male spragueDawley rats were used ( $C-D$ strain, obtained from Charles River Breeding Laboratories), which were 15 or 16 months old at the start of the exporiment. Animals of approximately equal weight (within $15 \mathrm{~g}$ ) and in apparent good health were selected and divided at random into three groups of twelve rats each. Rats in each group were given subcutaneous injections three times a week. One group received $1 \mathrm{U} / \mathrm{kg}$ of posterior pituitary extract prepared by suspending 'Powder Posterior Pituitary U.S.P.' (Lilly) in saline. The second group received $1 \mathrm{U} / \mathrm{kg}$ of synthetic oxytocin, 'Syntocinon' (Sandoz), diluted in saline, and the control group was treated with saline.

While no significant difference was observed between the number of surviving rats in either of the two treated groups and those in the control group during the early' months of the experiments, after a year a difference was apparent. The results of our investigations are summarized in Table 1, which shows the number of survivors at the end of each month of the experiment.

Our experiment seems to confirm the findings of Friedman and Friedman concerning the life-prolonging effect of the chronic administration of posterior pituitary extract in the rat but, at the same time, points to oxytocin

Table 1. NUmber of Rats surviving at the End of Each Month

\section{Month}

$\begin{array}{lrrrrrrrrrrrrrrrrrr}\text { Treatment } & 1 & 2 & 3 & 4 & 5 & 6 & 7 & 8 & 9 & 10 & 11 & 12 & 13 & 14 & 15 & 16 & 17 & 18 \\ \text { Saline } & 11 & 11 & 10 & 9 & 8 & 8 & 8 & 7 & 7 & 6 & 5 & 2 & 2 & 2 & 1 & 1 & 1 & 0 \\ \begin{array}{l}\text { Post. } \\ \text { pituitary }\end{array} & 11 & 10 & 10 & 10 & 10 & 10 & 9 & 9 & 8 & 8 & 8 & 7 & 5 & 3 & 3 & 3 & 0 & 0 \\ \text { Oxytocin } & 12 & 10 & 9 & 8 & 8 & 8 & 8 & 8 & 7 & 7 & 6 & 6 & 5 & 4 & 4 & 3 & 2 & 0\end{array}$

as the most probable factor responsible for this phenomenon. It seems to be quite possible that oxytocin, in addition to being a hormone which causes ejection of milk and contraction of the uterus, may have also an as yet undisclosed, more general role in the lifo processes. Its occurrence in the male and in non-mammals is also suggestive in this respect.

\section{Miklos Bonanszky} STANFORD L. ENGEL

The Squibb Institute for Medical Rosearch, New Brunswick, New Jersey.

${ }^{1}$ Friedman, S. M., and Friedman, C. L., Nature, 200, 237 (1963). 2 Friedman, S. M., and Friedman, C. L., Exp. Gerontology, 1, 37 (1964).

\section{Peritrophic Membranes in Arachnida (Arthropoda)}

Peritrophic membranes have been studied in insects from the microscopic ${ }^{1}$, submicroscopic ${ }^{2}$ and histochemical $^{2-4}$ point of view. The lack of information about this structure in arachnids has already been emphasized $^{5,6}$. I therefore present some moro bibliographical and histological data on this subjoct.

Tulk in 1843 (ref. 7) gives a description of a membrane which completely surrounds the oxcreta in the stomach in Phalangium opilio (Latr.). Plateau ${ }^{8}$ indicates some of the chomical properties of such a membrane in the distal part of the midgut in Agelena labyrinthica, and presents figures of a membrane that envolopes the excrementa of Argyroneta and Epeira umbratica (these three species belonging to the Araneidae). The histological work of Millot ${ }^{9}$ on spiders also gives a description of a basophil mombrane, formed by the fusion of distinet droplets round the excrements in the midgut, just behind the outlet of the abdominal diverticulao. This author gives no details concerning the species in which he observed the membrane. De Mets ${ }^{5}$ gives electron microscopic figures of the peritrophic membrane in the horseshoe 'crab' Xiphosura polyphemus, whereas Grainge and Pearson ${ }^{6}$ describe a membrane of $0.5 \mu$ thick in some Phalangidae.

I observed a peritrophic membrane in the cloaca (Fig. 1) and the midgut (Fig. 2) of Linyphia triangularis (Cl.), (Araneidae), a web-spinning spider, as woll as in the postdiverticular midgut of the gardon-spider Araneus diadematus (Cl.) (Fig. 3).

The histological preparations (fixation in Bouin and paraffin sections of $8 \mu$ ) are stained with haematoxylin at $p \mathrm{H} 3$ and potassium alum, and counterstained with erythrosine. The blue colour of the peritrophic membrane contrasts with the reddish base-tone of the gut contents and excrements and indicates their basophilic nature. Its

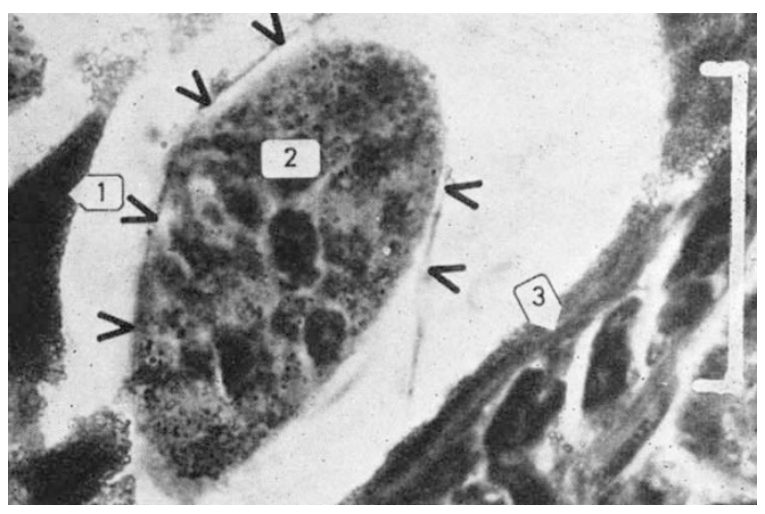

Fig. 1. Linyphia triangularis: guanine excretion (1); fiecal pellet (2) with cellular debris; cloacal wall (3). 'The ' $V$ ' signs point to the peritrophic membrane. Scalc $=50 \mu$ 